Alexandr V. Astafiev', Alexey A. Orlov², Denis G. Privezentsev ${ }^{3} \quad$ DOI: 10.25045/jpit.v11.i1.03 Murom Institute of Vladimir State University, Murom, Russia

${ }^{1}$ Alexandr.Astafiev@mail.ru, ${ }^{2}$ AlexeyAlexOrlov@ gmail.com, ${ }^{3}$ DGPrivezentsev@mail.ru

\title{
TECHNOLOGY OF AUTOMATION OF IDENTIFICATION OF OBJECTS IN THE PROCESS OF THEIR MOVEMENT ON NON-TYPED ROUTES USING MULTI-CODE LABELING
}

\author{
Received: 25.01.2019 \\ Revised: 29.03.2019 \\ Accepted: 27.06.2019
}

The article considers the relevance of the modernization of the methods and algorithms of nondestructive testing at industrial enterprises. It describes a practical problem solved by the developed technology - identification of products in stochastic motion on the example of Vyksa metallurgical plant (pipe-electric welding shop No. 3). Popular modern technologies for the organization of nondestructive control in the control systems of movement of industrial production are explored. The article proposes an approach of multi-code labeling of transported products to reduce the number of redundant manipulations for turning the identifier into the reading sensor. The definition of multi-code labeling is given. Classical methods of the integrity control and their practical application, as well as the possibility of their use for the generation of multi-code labeling are considered. The article analyzes the checksum method for creating multi-code labeling and develops an algorithm for their generation. The proposed approach will allow to organize the automatic control of the movement of industrial products without the introduction of additional stages of the production process aimed at positioning products relative to the sensor, as well as to obtain additional statistical data for the modernization of the tracking process.

Keywords: positioning, RTLS-systems, radio frequency identification, RFID, technical vision, multi-code labeling, movement control systems.

\section{Introducion}

According to the program "The development of the digital economy in Russia until 2035," one of the technologies that determines the transition to a digital economy is the identification technology [1] which the project aims to develop. The implementation of the project will allow switching to the deserted control of product movement by reducing the requirements for installing sensor equipment and additional control and self-monitoring algorithms.

Currently, due to the need for the development of industry and the implementation of the international quality standards, the introduction of new high-tech technologies to control the movement of products is required. The implementation of such control is possible through the introduction of automatic identification and recognition systems. The degree of perfection of the motion control system (ACS) of products depends on the efficiency of production in general. According to the standard GOST R 56542-2015 [2], there are 9 methods of non-destructive testing two of which have found wide practical application in ACS: radio frequency identification and technical vision. Both approaches have their advantages and disadvantages, but the main requirement for ACS products built using any of the technologies is the direct visibility of the labeling by the reading sensor.

Due to this limitation, most of the developed automatic ACS work on the principle of a stationary mounted sensor where the movement of controlled products is carried out strictly along this sensor. Such ACS are widely used in industrial plants with conveyor lines. In cases with more complex logistical mechanics, the reliability of such systems is extremely low. In practice, more complex SKDs are used in which the sensors are located on the transporting devices as such. However, the identification accuracy of those often does not exceed $95 \%$, and the construction of logistic routes occurs with the condition of turning the marking towards the reading device which increases the time for transportation and requires more whereby their work is challenged.

To reduce the time for the transportation and installation of additional equipment at the 
enterprises, the use of the multi-code labeling approach is proposed. The multi-code labeling approach consists of marking the product with single-type identifiers from several sides, so that at least one of them always comes into the field of view of sensors at any position of the product relative to the sensor. The use of multi-code labeling leads to redundancy, however, if we look at the problem from the other side and use a set of different, but interrelated identifiers for product labeling, we can organize additional motion control and prevent a number of emergency situations associated with the intentional change $[3,4]$.

The aim of the work is to study the possibilities of employing the approach of multi-code labeling of the dynamic objects for automating their identification in the process of stochastic movement.

In the process of project implementation, it is proposed to analyze the information integrity control algorithms (control number, CRC, hash functions and their specific implementations) and to build rainbow tables of these algorithms to extract new knowledge in the field of automation of production processes [5-13]. It is planned to conduct the research in the field of multi-code labeling of moving objects: consideration of their composition, as well as the methods of generation and identification. It is proposed to develop the methods for organizing the control and self-monitoring of transactions in automated processes for identifying and correcting the identification errors and predicting abnormal situations.

\section{Subject overview}

Currently, the integrity control methods have proven themselves in the field of network technologies (TCP / IP, TCPx / SPx, and others) to control the data transmission, and for ensuring information security of computer systems [14-16].

The use of rainbow matrices in other areas of activity is less common, but it brings significant success. For example, in article [17], researchers propose a new method of indexing static sequences of numbers using rainbow tables. The use of rainbow tables reduced the running time of the algorithms. In their publication, the authors Korzhik V.I. and Panteleeva Z.A [18] study the issue of recovering the passwords using the rainbow tables method.

Author Pilshchikov D.V. in work [19] discusses the balancing of memory and data time while working with rainbow tables. In this regard, it can be concluded that conducting additional fundamental research in the field of working with rainbow tables of integrity control methods is a topical scientific and technical problem.

The development of software and hardware SKD based on radio frequency identification and technical vision includes: PCT-Invent (Russia, Saint-Petersburg), ITProject (Russia, Moscow), Group of Companies "Lumenta" (Russia, Cherepovets) by Mullen Systems (Russia, Cherepovets), ACS (Russia, St. Petersburg), Beward (Russia, Moscow), Basler (Germany, Ahrensburg), Impinj (USA, Seattle), Motorola (USA, Morrisville), Nordic ID (Finland, Salo), FEIG (Germany, Weilburg) and many others.

A common shortcoming of existing identification methods is that for organizing an automatic control of movement, the reading devices are installed stationary, and the movement of the monitored product occurs as it passes along this device. It is imperative that the marking is in direct line of sight for the reader which is practically impossible when using such transport devices as bridge cranes, loaders, stackers and other means of small-scale mechanization. The movement of the products in this type of transportation is stochastic in nature, and the location of the cargo may obscure the direct visibility of the reader to the labeling.

The use of data from high-tech technologies [20-25] allows to automate the processes of monitoring of the movement of industrial products in the enterprises of various spheres and, ultimately, to improve the efficiency and accuracy of the monitoring of transportation and inventory control of manufactured products. However, they are not without flaws. The use of existing software and hardware solutions is more aimed at the organization of the automated warehouse accounting and is less suitable for the automation of motion control. In confirmation of 
this, the developers of RFID systems in a number of industrial enterprises in the Vladimir region and neighboring regions have attempted to organize the product traceability by automatically controlling movement based on radio frequency identification.

As a result, it turned out that automatic the control of the movement of industrial products is possible only in certain areas of the production process. Such sections are conveyor lines and transport tunnels where product is transported along the stationary-installed radio frequency identification equipment (RFID tunnels). In the remaining production and storage areas, the implementation of the automatic control of the movement of products is impossible. This is due to the lack of methods and algorithms for product identification in the process of its transportation along untyped routes (for example, stackers, loaders, cranes, etc.) and the difficulty of orientation of the goods being moved with the marked side to the sensor.

A large number of uncertainties of logistic routes of technological processes, the strict requirements of standardization bodies, possible errors in equipment installation, as well as the errors of the first and second kind of identification algorithms as such do not allow moving from the automated motion control to the automatic one. Therefore, the research is needed to find additional data sources, methods for their analysis, allowing to increase the share of successful identification of tagged objects.

\section{Analysis of the applicability of rainbow tables of integrity control methods for generating multi-code labelings}

The paper proposes to organize the relationship of identifiers that are part of multi-code labeling based on rainbow tables of integrity control methods. To do this, it is necessary to review the existing methods of integrity control and conduct a preliminary assessment of the possible number of sets of identifiers and their number in the set depending on the original alphabet and the length of the identifiers. Table 1 shows the values of possible number of sets and identifiers in them when using the alphabet of 10 characters: $0 . .9$.

Table 1

Values of the possible number of sets and identifiers in them when using the alphabet of 10 characters

\begin{tabular}{|l|l|l|l|l|l|}
\hline $\begin{array}{l}\text { Integrity control } \\
\text { method }\end{array}$ & $\begin{array}{l}\text { Check } \\
\text { number }\end{array}$ & Parity bit & $\begin{array}{l}\text { Ligament } \\
\text { method }\end{array}$ & $\begin{array}{l}\text { Cyclic redundancy } \\
\text { code (CRC) }\end{array}$ & Hash \\
\hline $\begin{array}{l}\text { Possible number of } \\
\text { sets }\end{array}$ & $\begin{array}{l}10,100, \\
1000 \text { etc. }\end{array}$ & 2 & $\begin{array}{l}10,100, \\
1000 \text { etc. }\end{array}$ & $\begin{array}{l}\text { CRC-8: 255 } \\
\text { CRC-16: } 56535 \\
\text { CRC-32: 4 294 } \\
967296 \text { etc. }\end{array}$ & $36^{64}, 36^{128}, 36^{256}$ etc. \\
\hline $\begin{array}{l}\text { Possible number of } \\
\text { unique identifiers }\end{array}$ & $\begin{array}{l}10, \quad 100, \\
1000 \text { etc. }\end{array}$ & $\begin{array}{l}10,100,100 \text { etc. } \\
1000,100,\end{array}$ & $\begin{array}{l}10 . . \infty \\
1000 \text { etc. }\end{array}$ & $\begin{array}{l}\text { Values are } \\
\text { computationally } \\
\text { more complex }\end{array}$ \\
\hline
\end{tabular}

Based on the analysis performed, it can be concluded that the control number, the bundle method and the cyclic redundancy code have potential for the consideration by the integrity control methods. The hash function methods are too complex to build rainbow tables, and the parity bit method has also few possible sets.

\section{Algorithm of generation of unique numerical sequences for systems for controlling the movement of industrial products}

The operation of the generation of unique numeric multi-code labelings for the systems of motion control of industrial products can be described as a sequence of the following steps:

1. Generation of a unique item number and its verification for existence in the database.

2. If the number does not exist, a set of identifiers is created; otherwise, item 1 is executed.

3 . The resulting numeric values are connected in a single number using a separator.

4. The generated number is loaded into the database.

Thus, using the control number method, an alphabet of 10 characters (0-9) and a maximum 
length of 15 characters, we can get up to 999999999999990 sets of labels with 10 unique values. An example of the formation of multi-code labeling is presented in figure 1:

The storage field for the unique ID number in the set

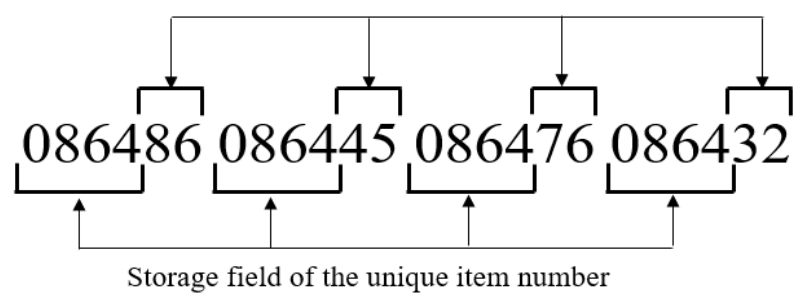

Figure 1. Example of the formation of multi-code labeling

The developed algorithms and a web application are introduced at the warehouse of packaging materials of the Global33 Group of Companies of the Vladimir Region to organize an automatic traceability of the shipment of air bubble film rolls along a conveyor line.

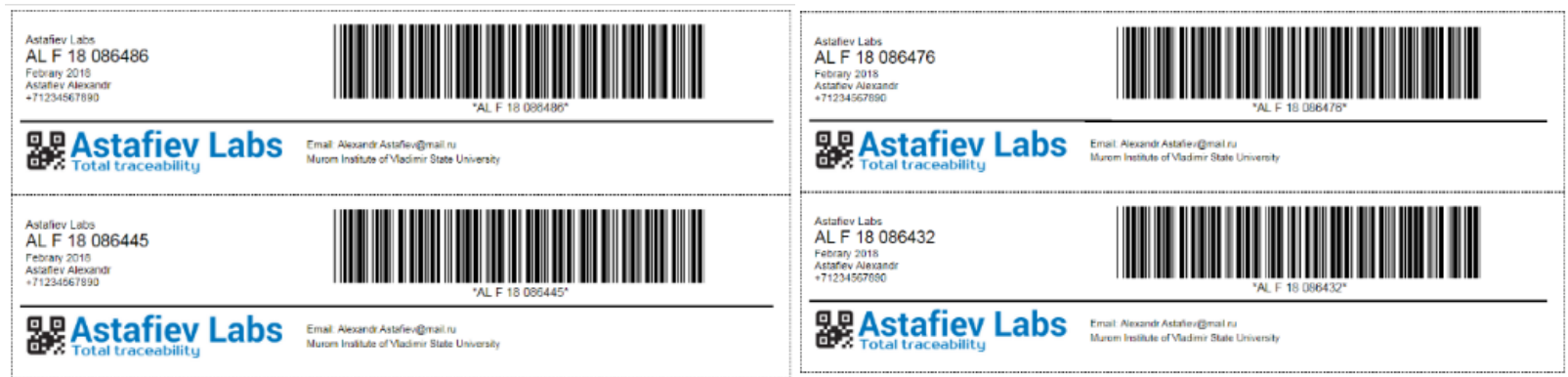

Figure 2. Example of multi-code labeling

\section{Conclusion}

The article was devoted to the development of technology, mathematical approach and software for the construction of positioning systems and motion control of small-scale mechanization of industrial enterprises on the basis of radio-frequency identification methods which will be the basis for the creation of high-performance intelligent control systems for the movement of the products in industrial enterprises. The basic standards operating in the field of automation of control of production movement and radio-frequency identification were considered. The review of modern publications and systems of automation of control of movement of production of domestic and foreign producers was carried out. The description of the developed algorithm of positioning of means of small mechanization at an industrial enterprise was given. Experimental research in laboratory and production conditions are carried out and described.

The study was carried out with the financial support of the grant of the President of the Russian Federation № MK-991.2017.9.

\section{References}

1. Order of the Government of the Russian Federation of 28.07.2017 N 1632-p On approval of the program "Digital economy of the Russian Federation".

2. $\quad$ GOST R 56542-2015 "Nondestructive control. Classification of types and methods."

3. Orlov A.A., Astafyev A.V., Provotorov D.G. Development and implementation of the localization algorithm for symbolic marking of pipe products based on a sequential two-dimensional search for the averaged maximum // ChSU Bulletin, 2015, №6, pp. 34-37. ISSN 1994-0637.

4. Orlov A.A., Astafiev A.V., Provotorov A.V. Methods and algorithms for automatic two-step video identification of metal-roll billets [Text] // Automation in industry, 2013, no 10, pp.53-57.

5. State Technical Commission of Russia, "Guidance Document: Protection against unauthorized access to information. Terms and definitions", Moscow: Military Publishing House, 1992.

6. Vatutin E.I., Titov V.S. Estimation of the real performance of modern processors in the problem 
of matrix multiplication for a single-threaded software implementation using the SSE extension (part 1) // News of South-West State University, 2015, vol. 1, no. 4 (61), pp. 26-35.

7. Vatutin E.I., Titov V.S. Estimation of the real performance of modern processors in the problem of multiplying matrices for single-threaded software implementation using the SSE extension (part 2) // News of South-West State University, 2015, vol. 1, no. 5 (62), pp. 8-16.

8. Popov D.V., Vatutin E.I. Analysis of the effectiveness of the use of GPGPU technologies in the implementation of heuristic algorithms in problems on graphs // Visual Analytics 2017. Kemerovo: Kuzbassvuzizdat Publishing House, 2017, pp. 37-39.

9. Vatutin E.I., Panishchev V.S., Gvozdeva S.N., Titov V.S. Weighted random iteration method for constructing partitions of graph-schemes of parallel algorithms when designing logical multicontrollers // Izvestiya SUSU, 2017, vol. 21, no. 6 (75), pp. 6-21. DOI: 10.21869/2223-1560-2017-21-6-6-21.

10. Vatutin E.I., Titov V.S, Emelyanov S.G The Basics of Discrete Combinatorial Optimization M .: ARGAMAK-MEDIA, 2016. 270 p.

11. Vatutin E.I., Titov V.S. Peculiarities of meta-optimization of the bee colony algorithm in the task of finding the shortest path in a graph with restrictions on the density of a graph // News of South-West State University. Series: Management, Computer Engineering, Computer Science. Medical Instrument. 2016, no. 2 (19), pp. 52-65.

12. Cavecchia V., Asnicar F., Masera L., Blanzieri E., Moser C. Optical-electronic devices and devices in systems of pattern recognition, processing images and character information. Recognition - 2017, a collection of materials of the XIII International Scientific and Technical Conference. 2017, Publisher: South-West State University (Kursk).

13. Asnicar F., Erculiani L., Galante F., Gallo C., Masera L., Morettin P., Sella N., Semeniuta S., Tolio T., Malacarne G ., Engelen K., Argentini A., Cavecchia V., Moser C., Blanzieri E.E. Volunteer Computing // Proceedings - 14th IEEE International Conference on Trust in Computing and TrustCom 2015, Volume 3, 2015, vol.3 pp. 248-253

14. Mun H.J., Hong S., \& Shin J. Erratum, 2017. Cluster Computing, 2017, https://doi.org/10.1007/s10586-017-0984-3

15. Marechal S. Advances in password cracking // Journal of Computer Virology, 2008, https://doi.org/10.1007/s11416-007-0064-y

16. Mun H.J., Hong S., \& Shin Ack, Rising, Rainbow, Tablets // Journal of Cluster Computing, 2017, https://doi.org/10.1007/s10586-017-0886-4

17. Jungjoo Seo, Myoungji Han Efficient Accessing and Sequence of Numbers, Journal of Computing Science and Engineering, 2015, vol. 9, no. 1, pp. 1-8

18. Korzhik V.I., Panteleeva Z.A. Study of the method of rainbow tables for password recovery // Actual problems of infotelecommunications in science and education II International Scientific-Technical and Scientific-Methodical Conference, 2013, St. Petersburg State University of Telecommunications.

19. Pilshchikov D. Study of the Complexity of the Rainbow Table Method with Chain Markers // Mat. vopr. Cryptogram., 2017, vol. 8, no 4, pp. 99-116.

20. Bondarevsky A.S., Zolotov R.V. Radio Frequency Identification (RFID) Design - Problem Situation / Modern High Technologies, 2009, no 9, pp. 19-23.

21. Until Zuy. Nyat Research and application of RFID technology // International Research Journal, 2015, no 6 (37) Part 1, pp. 34-37.

22. Kamozin D.Y. Comparison of the effectiveness of the use of bar-coding technology and RFID technology in logistic processes // News of IGEGOST R ISO / IEC 15459-3-2007 "Automatic identification. Identifiers are unique international. Part 3. General rules for unique identifiers"

23. Ke-Sheng W. Intelligent and integrated RFID (II-RFID) system for improving traceability in manufacturing / Advances in Manufacturing, 2014, vol. 2, no 2, pp. 106-120.

24. Worapot J., Somjit A., Yuefeng L. Erratum to: An RFID-based traceability system / 
Telecommunication Systems, 2015, vol. 58, no 3, pp. 273-273.

25. Mahir O., Alp U., Aysenur B. An RFID-based tracking system for denim production processes / The International Journal of Advanced Manufacturing Technology, 2016, pp. 1-14.

\section{UOT 004.021}

\section{Astafiyev Aleksandr V. ${ }^{1}$, Orlov Aleksey A. ${ }^{2}$, Privezentsev Denis G. ${ }^{3}$}

Vladimir Dövlət Universitetinin Murom filialı, Murom, Rusiya

1Alexandr.Astafiev@mail.ru, ${ }^{2}$ AlexeyAlexOrlov@gmail.com, ${ }^{3}$ DGPrivezentsev@mail.ru

Çoxkodlu işarələmənin istifadəsi ilə qeyri-tipli marşrutlarda obyektlərin hərəkəti zamanı onların identifikasiyasının avtomatlaşdırılması texnologiyası

Məqalədə sənaye müəssisələrində fasiləsiz nəzarət metodları və alqoritmlərinin müasirləşdirilməsi məsələsinin aktuallığına baxılmışdır. Təklif edilmiş texnologiya vasitəsilə həll edilən praktik məsələ - V1ksa metallurgiya zavodunun (3 saylı boruelektroqaynaq sexi) nümunəsində stoxastik hərəkət zamanı məhsulun identifikasiyası məsələsi təsvir edilmişdir. Sənaye məhsulunun hərəkətinə nəzarət sistemlərində fasiləsiz nəzarətin təşkili üçün geniş yayılmış müasir texnologiyalara baxılmışdır. İdentifikatorun yığım sensoruna dönməsi üçün artıq manipulyasiyaların miqdarının azalması üçün nəql edilən məmulatların çoxkodlu işarələnməsi yanaşması təklif edilmişdir. Çoxkodlu işarələnmənin tərifi verilmişdir. Klassik tamlığa nəzarət metodları və onların praktiki tətbiqi sahələrinə, həmçinin çoxkodlu işarələnmənin generasiyasında istifadə imkanlarına baxılmışdır. Tədqiqat işində çoxkodlu işarələnmənin yaradılması üçün nəzarət cəmi metodunun analizi aparılmış və onların generasiyası alqoritmi işlənmişdir. Təklif edilmiş yanaşma, sensor haqqında məmulatların yerləşdirilməsinə istiqamətlənmiş istehsal prosesinə əlavə mərhələlər tətbiq edilmədən sənaye məhsulunun hərəkətinə avtomatik nəzarətin təşkil edilməsinə, həmçinin izləmə prosesinin müasirləşdirməsi üçün əlavə statistik məlumatların əldə edilməsinə imkan verəcəkdir.

Açar sözlor: yerlaşdirmə, RTLS-sistemlar, radiotezlik eynilaşdirməsi, RFID, texniki görmə, çoxkodlu işaralama, harakata nazarat sistemlari.

\section{УДК 004.021}

\section{Астафьев Александр В. ${ }^{1}$, Орлов Алексей А. ${ }^{2}$, Привезенцев Денис $\Gamma_{.}^{3}$}

Муромский филиал Владимирского государственного университета, Муром, Россия

1Alexandr.Astafiev@mail.ru, ${ }^{2}$ AlexeyAlexOrlov@gmail.com, ${ }^{3}$ DGPrivezentsev@mail.ru

Технология автоматизации идентификации объектов в процессе их движения на нестандартных маршрутах с использованием многокодовой маркировки

В статье рассмотрена актуальность модернизации методов и алгоритмов неразрушающего контроля на промышленных предприятиях. Описана практическая задача, решаемая разработанной технологией - идентификации продукции при стохастическом движении на примере Выксунского металлургического завода (трубоэлектросварочный цех №3). Рассмотрены популярные современные технологии для организации неразрушающего контроля в системах контроля движения промышленной продукции. Предложен подход мультикодовой маркировки транспортируемых изделий для снижения количества избыточных манипуляций для поворота идентификатора к считывающему сенсору. Дано определение мультикодовой маркировки. Рассмотрены классические методы контроля целостности и области их практического применения, а также возможности их использования для генерации мультикодовых маркировок. В работе проведен анализ метода контрольных сумм для создания мультикодовых маркировок и разработан алгоритм их генерации. Предложенный подход позволит организовывать автоматический контроль движения промышленной продукции без введения дополнительных этапов производственного процесса, нацеленных на позиционирование изделий относительно сенсора, а также получать дополнительные статистические данные для модернизации процесса прослеживания.

Ключевые слова: позиционирование, RTLS-системы, радиочастотная идентификация, RFID, техническое зрение, мультикодовая маркировка, системы контроля движения. 